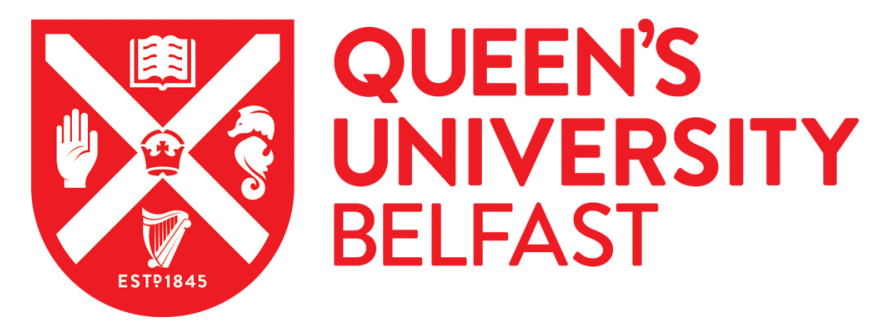

\title{
Jazz in Athens: Frustrated Cosmopolitans in a Music Subculture
}

Tsioulakis, I. (2011). Jazz in Athens: Frustrated Cosmopolitans in a Music Subculture. Ethnomusicology Forum, 20(2), 175-199. https://doi.org/10.1080/17411912.2011.592670

\author{
Published in: \\ Ethnomusicology Forum
}

Document Version:

Peer reviewed version

Queen's University Belfast - Research Portal:

Link to publication record in Queen's University Belfast Research Portal

\section{Publisher rights}

Copyright 2011 Taylor and Francis.

This is an Accepted Manuscript of an article published by Taylor \& Francis in Ethnomusicology Forum on 12 Aug 2011, available online: http://www.tandfonline.com/doi/abs/10.1080/17411912.2011.592670

\section{General rights}

Copyright for the publications made accessible via the Queen's University Belfast Research Portal is retained by the author(s) and / or other copyright owners and it is a condition of accessing these publications that users recognise and abide by the legal requirements associated with these rights.

Take down policy

The Research Portal is Queen's institutional repository that provides access to Queen's research output. Every effort has been made to ensure that content in the Research Portal does not infringe any person's rights, or applicable UK laws. If you discover content in the Research Portal that you believe breaches copyright or violates any law, please contact openaccess@qub.ac.uk. 


\title{
Jazz in Athens: Frustrated Cosmopolitans in a Music Subculture ${ }^{1}$
}

Ioannis Tsioulakis

\begin{abstract}
This paper presents an ethnographic account of jazz music in Athens. The small scene under scrutiny is mainly populated by professional session instrumentalists of the Greek popular music scene who perform jazz as a side activity for their own pleasure. In the process, they construct a conceptual dichotomy between 'work' and 'play'. Drawing on the author's extended involvement in this scene, and focusing on private interviews with musicians, this article unveils the discourses of cosmopolitanism invoked through local jazz music making. The ethnographic material presented aims to illustrate how even a small subculture can serve as a terrain for contesting cosmopolitan imaginaries.
\end{abstract}

Keywords: Jazz; Ethnic-Jazz; Greece; Professional Musicians; Cosmopolitanism; Social Imaginary; Subculture

\section{Introduction}

Jazz music exists as an almost invisible subculture in Athens. Being immersed in the jazz scene since finishing secondary school in 1998, I was unaware of how negligible it was considered by outsiders until I started discussing the prospect of focusing on it for my doctoral research. I still remember the response I received from an Athenian postgraduate student in ethnomusicology at that time: 'Looking for jazz in Athens is like looking for feta

\footnotetext{
${ }^{1}$ This article is an expanded version of the prize-winning student paper presented at the 2008 annual conference of the British Forum for Ethnomusicology, held at Cardiff University. I am grateful to Marina Roseman, Suzel Ana Reily and the two anonymous reviewers for their insightful comments on earlier versions of this text.
} 
cheese in Denmark; you might find some but it will taste like crap'. Despite the mixed reactions of my academic colleagues, I proceeded with field research among Athenian jazz musicians that lasted from January 2008 to June 2009. In the process, I found myself further challenged by the musicians themselves. Whilst attempting to arrange interviews with some of the most established musicians of the small Athenian jazz scene, I regularly received answers along the lines of 'well, I wouldn't really call myself a jazz musician'. Some even proposed others as 'real' jazz musicians that I should consider interviewing and with whom they offered to put me in contact. On more than one occasion, I was directed to musicians with whom I had already communicated and who had initially given me the exact same response. Interestingly, the same people who hesitated to label themselves as 'jazz' musicians, were less reluctant to play 'jazz' music, and have been doing so - some of them with myself - for the past several years. In order to overcome this difficulty, I started to replace the term 'jazz musician' with 'a person involved in the jazz music scene' with which musicians seemed more comfortable.

This apparent inconsistency between characterisation (jazz musician) and practice (playing jazz) suggests charged local meanings attached to the term 'jazz musician' that go beyond the obvious one of 'a person playing jazz'. The term is regarded as an assessment of skill and technique (the ability to play jazz well), includes notions of authenticity (playing jazz as it is 'meant to be played'), and most importantly has to do with a wider attitude and way of life that is connected to the imaginary of the jazz musician: living the jazz life. The reluctance of individuals to identify themselves as jazz musicians also resonates with a pervasive aphorism often expressed by jazz-trained professional instrumentalists: 'this country has no room for jazz musicians'.

This article examines the ways in which jazz musicians in Athens articulate their practices. Based on a number of interviews and my own extended involvement in the Athenian jazz scene, I seek to uncover the contested ideologies and imaginaries which connect jazz with current ethnomusicological discussions on cosmopolitanism and music 
subcultures. ${ }^{2} \mathrm{~A}$ brief review of the literature concerning globalisation and cosmopolitanism as analytical concepts within anthropology and ethnomusicology will lead to a suggested view of imaginaries as the constituting terrain for cosmopolitan ideologies; following this, the case study of jazz-trained professional musicians in Athens will seek to show the ethnographic applicability of this view.

\section{Globalisation and the Cosmopolitan Imaginary}

During the 1990s, postcolonial theory attempted to challenge the one-sided narrative of globalisation as an upcoming grey-out caused by cultural imperialism, conceptualising it instead as a series of asymmetrical flows (Hannerz 1992:217-63). ${ }^{3}$ Arjun Appadurai's work (for instance 1990, 1996) has proven particularly influential: his view of '-scapes' suggests a reading of globalisation processes that is sensitive to the simultaneous and often contradictory roles of media, capitalism, nationalism, technologies and the human imagination. From this perspective, globalisation is no longer viewed as a monolithic, irreversible, homogenising force from above, but rather an unending canvas of emerging possibilities generated by local negotiations of transnational currents.

The relative optimism of the 'flows' and '-scapes' approaches of the 1990s was succeeded by intense scepticism at the dawn of the new millennium. Scholars problematised the portrayal of globalisation as flows, pointing to its failure to account for the exclusivity and unevenness of the processes (Inda and Rosaldo 2008:6). In this light, Anna Tsing's conception of 'globalisms' described phenomena that 'need to be interrogated as an interconnected, but not homogeneous, set of projects - with their distinctive cultural commitments and their powerful but limited presence in the world'

\footnotetext{
${ }^{2}$ The quotations in this article are taken from private semi-structured interviews that took place between January 2008 and June 2009 in Athens. Some of the names have been changed in cases where informants have chosen to remain anonymous

${ }^{3}$ For a critique of the cultural imperialism narrative, see Born and Hesmondhalgh (2000:25).
} 
(2000:353). Thus, as recent anthropological work has asserted, globalisation should be seen as a set of actions and agencies, which often exist in conflict and opposition. In order to capture the ways in which globalist discourses and processes come into being through local and individual agencies, Thomas Turino proposes 'cosmopolitanism' as a potentially useful term (2000), suggesting moreover that 'cosmopolitan formations' have their own 'habits and resources for living' (2003:61) and are themselves culturally grounded. These cosmopolitan formations, much like Tsing's 'globalist projects', represent cultural, political and nationalistic agendas that may be complementary or contradictory. In this sense, Turino speaks of 'cosmopolitan subjectivities' as a 'crucial site of the local - trans-local dialectics' (2003:63). Similarly, Martin Stokes has advocated the relevance of 'cosmopolitanism' as an analytical tool within ethnomusicology, since it 'restores human agencies and creativities to the scene of analysis, and allows us to think of music as a process in the making of "worlds", rather than a passive reaction to global "systems" (2007:6).

Mark Slobin's idea of 'affinity interculture' (1993:68) offers a valuable approach for understanding how competing cosmopolitan formations are created, sustained and fed. ${ }^{4}$ Musical choices, Slobin argues, can represent ideological and aesthetic affinities across the world. Although often based on extreme cultural misunderstanding, these affinities are able to motivate major intercultural processes. ${ }^{5}$ Within Slobin's understanding, music ethnography can reveal the variety of meanings that a subculture encompasses while situated among, influenced by, counteracting, or oppressed by super- and intercultures. Drawing on Slobin's 'affinity interculture', I propose that an understanding of social imaginary (Castoriadis 1987; Gaonkar 2002; Taylor 2002) is most relevant in the

\footnotetext{
${ }^{4}$ In an important review of anthropological and ethnomusicological work on globalisation from 1980 to 2004, Stokes situates Slobin's ideas in the optimistic/liberal extreme of the spectrum (its Marxist counterapproach being characterised by the work of Veit Erlmann), since 'Its only consistently organizing force is consumer choice, which ... offers modern subjects more-or-less limitless opportunities for self-fashioning' (2004:49). I - conversely - take Slobin's terminology as a useful tool within Tsing's and Turino's conceptualisation of globalisation and cosmopolitanism as projects, since it alerts us to the consideration of social positioning, visibility, and power asymmetries between different domains of cultural production.

${ }^{5}$ George Lipsitz has argued that all cross-cultural exchanges and blends include an element of miscommunication, which can often be productive; he refers to this as 'creative misunderstanding' (1994:159-69).
} 
description of music networks that incorporate global/cosmopolitan aesthetics and ideologies.

Anderson (1983) has elaborated on the idea of the imagination as a constitutive force for communities as large as the nation. He posits that modern communities have been made imaginable by the interaction of capitalism, communications technology and the 'fatality of human linguistic diversity' caused by the generalised adoption of national languages that transcend territorial fragmentation represented by local dialects (46). The same could be said of cosmopolitanism (or transnationalism): capitalism has turned a portion of cultural artefacts into purchasable goods, allowing Inda and Rosaldo's 'de/territorialization' (2008:14) through an imaginary of transnational cultural engagement for anyone who can afford it. Moreover, the explosion of international communication through electronic technology, and the dissemination of the English language, have served as a means of cosmopolitan cultural exchange. Erlmann has previously applied the Andersonian paradigm to global-scaled phenomena specifically in relation to music, using the term 'global imagination' to denote 'the means by which people shift the contexts of their knowledge and endow phenomena with significance beyond their immediate realm of personal experience' (1999:4).

What I focus on here, however, is a more individual essence of the imaginary. Writing against the deterministic and structuralist approaches of scholars such as Levi-Strauss, Hegel, and of traditional Marxism, Cornelius Castoriadis (1987, 2000) argues that the claims of social theory to canonise and 'predict' social developments are unsuccessful because they fail to acknowledge the basic constitutive force for culture and society: the human imagination. According to his understanding, 'imagination, more than the ability to combine already given elements in order to produce a variation of a given form, is the potential of posing new forms. Of course, this new form utilises elements that already exist. But the form is in itself new' (2000:21). ${ }^{6}$ This perspective brings individual agency into the

\footnotetext{
${ }^{6}$ Translated from Greek by the current author.
} 
centre of cultural construction processes and situates creativity in the interplay between collective and individual imaginaries.

In writings by Dilip Gaonkar (2002) and Charles Taylor (2002, 2004) the social imaginary becomes more dialogical and its importance is relocated from the extraordinary creative force that constitutes change to a way of being-in-the-world. Rather than being the motivating factor behind significant historical moments of reformation (such as Castoriadis' examples of Classical Greece and the Renaissance), from this new perspective the social imaginary is closely related to cosmology (the way to view the world) and ontology (the way to view the self in the world). Thus, although sharing Castoriadis' view of the social imaginary as a 'generative matrix', Gaonkar emphasises 'its role in the hermeneutics of everyday life ... The social imaginary therefore occupies a fluid middle ground between embodied practices and explicit doctrines' (Gaonkar 2002:10). In Taylor's words, the term captures,

... the ways in which people imagine their social existence, how they fit together with others, how things go on between them and their fellows, the expectations that are normally met, and the deeper normative notions and images that underlie these expectations. (2002:106)

Such a conceptualisation of the social imaginary can be useful in music studies since it facilitates a re-focusing on individual agency and creativity in a way that avoids any elitist obsession over musical 'genius'. Therein lies its dialogical nature: the social imaginary is the field for a discourse between the extraordinary event and the everyday occasion, the historical past with the acting present and the intended future, the theory with the embodied practice and, most importantly, the individual with the collective.

This ethnographic study of Athenian jazz musicians serves as an illustration of cosmopolitan imaginaries at play through music. What will become apparent is that cosmopolitan musical affinities and practices are constructed simultaneously through reality and myth, experience and fantasy, harmony and struggle. In this light, my use of 'subculture' 
does not refer to a polemic or subversive counterculture, but rather to a subcultural ideology (Thornton 1995) where unshared cosmopolitan imaginaries find their occasional refuge.

\section{Towards a Reconstruction of Greek Jazz History}

Jazz music's dissemination around the world has had a major impact on local music scenes. Its focus on improvisation has made it a more suitable field for musical acculturation (Pinckney 1990) than Euro-American art music, establishing it as an early 'harbinger of what we now call "globalization”' (Atkins 2003:xiii) Moreover, the repetitive rhythm patterns (grooves) and melodic riffs characteristic of jazz have made it fruitfully adoptable within local popular musics (Monson 1999). The story of its intercultural travelling and local adaptation, however, is far from universally consistent. An examination of the ways in which jazz was introduced and appropriated in different localities provides a variety of scenarios in which 'seldom did the music's encroachment go uncontested' (Atkins 2003:xv). During the period of the Third Reich, for example, jazz was banned in Germany due to its association with 'blacks, Jews, and degeneracy' (Kater 1992:182). Ironically, Germany's Japanese allies were at that time using the same music as an anti-American cultural formation under the slogan 'jazz for country's sake' (Atkins 2001:93-126). The social significance of jazz as an imported idiom has also varied from one country to another: during the 1950s, jazz was associated with the upper classes in India (Pinckney 1990:38), whilst at the same time, in the Soviet Union, it served as a stylistic expression of dissident youth (Starr 1983:236-40). As this article will show, the story of jazz's presence in Athens not only negates conformation to a global pattern, but also shows an array of contradictory responses.

My attempt to trace the chronology of jazz music in the Greek context reveals a surprising discrepancy between oral accounts and the data contained in the limited relevant 
historiography and discography. Although the history of Greek elafró tragoúdi ('light song') includes a number of composers and performers from the early 1940s onwards who were evidently influenced by jazz (Milonas 2002), local jazz aficionados and musicians invariably propose that jazz in Athens has a history of only three decades (Haronitis 2005). An examination of the discography of elafró tragoúdi from the 1940s to the late 1960s suggests that composers such as Yiánnis Spártakos - referred to in the print media as 'the King of jazz" - and later Mímis Pléssas, were indeed fluent in the jazz idiom as revealed by their compositions and piano playing. ${ }^{8}$ Elements of jazz harmony and orchestration can also be found in songs by other important composers of the mid-twentieth century including Kóstas Yiannídis, Chrístos Hairópoulos and Yiórgos Mouzákis (Lykouropoulos 2005). The big bands and smaller ensembles employed in elafró tragoúdi recordings of this period exemplify an adequate competence in jazz playing techniques, especially among brass players. Whilst these musicians remained largely anonymous, their sonic imprint suggests the existence of a network of teachers who were, at least to some extent, familiar with jazz.

The history of 'westernised' elafró tragoúdi suggests that it was largely defined by its opposition to laïkó tragoúdi ('folk song'), ${ }^{9}$ a cultural conflict dating back to the early $1900 \mathrm{~s}$ and the antagonism between the cafés amán and cafés chantants (Liavas 2009; Tragaki 2007). At this time, the cafés amán hosted performances of anatolitika ('eastern-sounding') songs of the rebétiko tradition, something which was boosted by the arrival of migrants from Asia Minor and northeast Thrace. The cafés chantants, on the other hand, catered to the cosmopolitan tastes of the urban upper classes by featuring mostly Western European songs, with lyrics either translated into Greek or in the original language. This division between elafró and laïkó tragoúdi encapsulated a wider cultural/political debate around the construction of the 'modern Greek nation' defined by various Occidentalist and Orientalist

\footnotetext{
${ }^{7}$ Kathimerini (newspaper), August 1 2001,

http://news.kathimerini.gr/4dcgi/_w_articles_civ_2_01/08/2001_5000028 (Accessed June 16 2010).

${ }^{8}$ Their jazz influences can be heard in recording compilations such as Relaxing with Yiannis Spartakos and his Golden Trio (1975) and 40 Years of Jazz (Pléssas 1981).

${ }^{9}$ For a detailed examination of the aesthetics, politics and controversies surrounding the term laïkó tragoúdi see Tragaki (2005).
} 
discourses (Herzfeld 1982). The elafró tragoúdi culture - and with it the taste for jazzinfluenced compositions and arrangements - began its decline in the late 1960s with the emergence of the éntehno-laïkó ('art-folk') genre epitomised by composers Míkis Theodorákis and Mános Hatzidákis. This new genre managed, especially after the end of the Junta (1967-1974), to achieve an inter-class appeal through its utilisation of folk music idioms combined with intellectual poetry, embodying the romantic leftist patriotism of postdictatorship Greece (Cowan 1993; Papanikolaou 2007; Tragaki 2007). ${ }^{10}$

Contemporary jazz musicians in Athens, however, do not claim a connection with the elafró tragoúdi culture, despite the evident jazz training of some of its major representatives. Instead, they tend to refer to the trio Sphinx and its eponymous album, released in 1979, as the genesis of Greek jazz music (Haronitis 2006). This album features pianist Márkos Alexíou, bassist Yiórgos (or George as named on the LP cover) Filippídis and drummer Yiórgos Trantalídis (again George on the cover) performing jazz standards (including Miles Davis' 'Nardis' and Thelonious Monk's 'Round Midnight') and original compositions by Alexíou, in accordance with the long tradition of jazz trios being led by the pianist who is also the main composer. ${ }^{11}$ I argue that this lack of identification with the elafró genre reveals a wider ideological difference: contemporary jazz musicians in Athens see in elafró an expression of bourgeois cosmopolitanism rather than the musical intercultural dedication that drives their interest in jazz. This is indeed a story of competing cosmopolitan formations (Stokes 2007; Turino 2003), as will be discussed below. In any case, it was not until the early 1990s that an autonomous jazz scene developed in Athens. In 1993, the Jazz FM radio station was founded and the $J a z z \& T \zeta \alpha \zeta^{12}$ music magazine was first published. These media promoted many different kinds of jazz, from swing standards to contemporary

\footnotetext{
${ }^{10}$ Pinckney reports a similar situation in India, where the growth of nationalist, anti-Western feelings contributed to the decline of jazz in the 1950s (1990:37-8).

${ }^{11}$ For a sample of Sphinx's music, see: http://www.falireas.com/product_info.php?info=p33_Sphinx--The-first-Greek-JazzAlbum.html\&XTCsid=fn15frj8skuep7l2pvraefba45 (accessed 16 June 2010).

${ }^{12}$ The title features the word 'jazz' in English and Greek, thus denoting the magazine's intention to represent a balance between international and domestic jazz production.
} 
experimental pieces, while simultaneously advertising CD releases and concerts in the local scene. A number of clubs specialising in jazz opened, including the Half Note Jazz Club, the Paráfono Jazz Club, the Barákos Club and the Diva Club. The band Page One, whose two albums ${ }^{13}$ are among the very few examples of Greek jazz to feature in European CD shops, was formed in response to the needs of the Diva Club shows. Page One are commonly regarded as the most important mainstream jazz band in Greece to date. The category of 'mainstream jazz' was, at this time, not positioned in opposition to 'avant-garde jazz' or 'free-jazz' (as is often the case in the US jazz scene), but primarily signified a distancing from what was referred to as 'ethnic-jazz': jazz incorporating traditional Greek or other 'non-Western' idioms. As such, mainstream jazz was the style that sounded least Greek and thus generally perceived as being up to European - or even US - standards.

In 1990, the Philippos Nakas Conservatory - one of the largest music schools in Greece - established a jazz department which in 1992 became affiliated with the Berklee College of Music in Boston. This development had a dual effect: first, it gave employment to jazz musicians; and, second, it gave students the opportunity, especially those living in or near Athens, to receive a jazz education without having to leave the country. On these courses, students were introduced both to techniques of improvisation and jazz theory, whilst also having the opportunity to participate in ensembles directed by their - mainly foreign-educated - tutors. This small circuit of musicians, the single radio station, the dedicated magazine, the four specialised music venues, the educational foundation and the hundreds of eager students was what constituted the jazz music scene of Athens during the 1990s. Nevertheless, there was still one important thing missing: the audience.

By the following decade, when I was conducting my research in Athens, two of the specialised jazz clubs had closed down, and only one new one had opened. Additionally, the Half Note Jazz Club - the largest of the three - now seldom features Greek bands. Despite disapproval from musicians, this ensures the Half Note's popularity among

\footnotetext{
${ }^{13}$ Page One (1994) and Beyond the Blue (1995).
} 
audiences that are not trained in jazz. The radio frequency of Jazz FM was bought by a pop

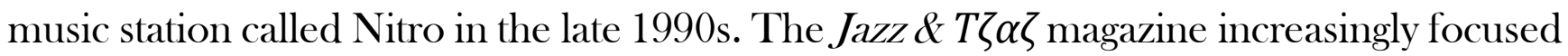
on world music, to the extent that many musicians consider it as having 'very little to do with jazz anymore' (Pantelís P., trumpeter). The jazz department of the Nakas Conservatory still exists, but in the words of one of its former teachers 'instead of the big names of the jazz scene it now employs their former students 'cause they're cheaper and they don't object to the rip-off that is working for ten euros an hour'. And the audience for jazz has not grown; the only quantity that seems to have disproportionally increased is that of professional skilled musicians. The eager hundreds of the 1990s are now qualified musicians who have either continued their education abroad or learned through obsessive album collecting and endless hours of transcribing improvisations:

In Paros island, summertime, I used to sit for hours and transcribe from Bill Evans albums, his bassists, you know, Scott LaFaro, things like that. Then it was already dark outside and I had missed my swim! (Pétros V., bassist)

I was working as a graphic designer at that time, and I kept taking night shifts so I could listen to Keith Jarrett when the office was quiet. (Vásso D., guitarist)

This training provided musicians with more than technical skill; it generated a new set of fantasies and expectations, referencing a locus where this music was believed to flourish, a 'promised-land' destination:

I was suddenly living in my own world. I would go out to the balcony and instead of my mum's flowerpots I'd see skyscrapers! I was in Thessaloniki dreaming of New York City. (Vásso D., guitarist)

Musicians gained experience through playing at the few jazz clubs for small audiences that generally consisted of their classmates or fellow musicians, and later on their own students. Along with musical training, they absorbed the frustration of their teachers at the lack of opportunities to play 'proper' jazz music in Greece. Technical directions in lesson were 
frequently followed by remarks such as 'but you will never need that, 'cause let's face it, you will be working behind some pop star and nobody will be paying attention at anything but her skirt' (Pantelís P., trumpeter).

\section{Working for the Popular Music Industry}

The fact that the number of trained jazz musicians was larger than the small Athenian circuit could support led musicians to seek employment in the popular music industry. The recording industry in Athens is largely controlled by the multi-national companies that dominate the Western popular music market and two Greek companies that are associated with large local broadcasting networks. ${ }^{14}$ Significantly, however, since most local popular music has Greek lyrics - with the almost unique exception of songs competing for the Eurovision Song Contest - this music tends not to be circulated abroad and is intended primarily for national consumption..$^{15}$ As a result, Greek pop stars usually maintain audiences and earn their income by performing at Athenian night clubs for seasons lasting roughly from October until March or April, usually performing four nights per week, Thursday to Sunday. Shows start after midnight and continue until 4am or 5am with no more than a 15 minute break. During the summer, musicians tour around Greece or play for Greek audiences abroad. Jazz musicians who choose to work for a specific singer find steady employment in these circumstances for the season, and even possibly the full year.

\footnotetext{
${ }^{14}$ Since the late 1990s, the Greek music industry has been a site of struggle between the multi-national corporations (Sony, EMI, Warner and Universal) and the Greek companies (Heaven and Legend) over the signing of established local pop stars. However, this has not affected the work of freelance instrumentalists who do not generally perceive this struggle as capable of bringing any qualitative changes to the local music market.

${ }^{15}$ Polychronakis (2007) presents an interesting case of a Greek pop star's brief success at reaching international audiences. In addition, the Greek diaspora serves as an enthusiastic audience for Greek popular music stars (see Panagakos, 2003). However, given the limited distribution of Greek recordings abroad, these audiences primarily contribute to the Greek music industry by attending the few concerts that are held in large Western urban centres.
} 
Greek popular music today includes various genres with diverse histories and influences, and charged with contradicting politics and aesthetics. The dominating genres are laïkó (urban-folk); pop, a westernised genre with Greek lyrics; and éntehno ('art-song') which derives from the éntehno-laïkó of the 1960s and 70s, discussed earlier. ${ }^{16}$ These genres are generally denigrated by jazz musicians as being of low quality, largely because of their verbal orientation - catchy rhymes for the pop and urban-folk; poeticised expression for the art-song - leaving little room for musical sophistication:

The problem is that this music is made only for the words, with the side-effect that the musician is 'pulled down'. It doesn't allow the musician to give it what it needs in order to be amazing. (Aléxandros K., drummer)

It's really bad that we don't have any instrumental music here. How can we have good players and bands if our music is only bouzoúki, guitar and a singing voice? (Antónis L., saxophonist)

In the Greek jazzman's ${ }^{17}$ view, music is an instrumental art and musicians can only explore their full potential in open compositional and improvisational forms. These forms, however, are not widely popular within Greece; thus, the musical tastes of Greek jazz musicians by definition lie outside Greece's borders. Even the art-song (éntehno) genre, generally regarded by audiences as belonging to the high quality end of the spectrum of Greek popular music, is dismissed by jazz musicians because of the perceived lack of musical training characteristic of many of the singer-songwriters who dominate its production:

Most of the singers and songwriters play by instinct. And, of course, they do make some good stuff by instinct. But this is not enough, because it is eventually limited by their ignorance. You can only explore yourself so much ... some of

\footnotetext{
${ }^{16}$ For a discussion of Greek popular music genres and their history, see Papanikolaou (2007), Tragaki (2005) and Cowan (1993).

${ }^{17}$ This term is widely used in the Greek jazz scene in its English form. The implied gender connotations are not perceived as problematic since the overwhelming majority of professional instrumentalists in Athens are male. This gender imbalance is even stronger in the jazz scene.
} 
them dropped out of schools of economics because they're making more money by playing a bit of guitar. But the industry should make special guitars for them with only three frets! Beyond those three there's no money! (Vásso D., guitarist)

Jazz musicians that I spoke to described working in these contexts as a necessary evil, a sacrifice to be made in order to earn a living. Their experience is measured by the amount of money made, the working conditions, and also the particular blend of instrumentalists which helps musicians to have fun while gigging or touring:

It's only the money that counts. How much you're getting. And if you're friends with the rest of the players it's easier. Time goes by. And if the songs are kind of decent, then you don't suffer. (Aléxandros K., drummer)

You always find something to focus on in order to enjoy a gig. If you don't really like the music then you focus on the tightness of the band, the attitude on stage, how good the rest of the players are. (Yiórgos L., drummer)

In these venues the brass players usually play just at the first session. So then, if you're lucky you get to go home. If not, you have to stay there and you can study scales to pass your time. (Pantelís P., trumpeter)

After Antónis D., a young saxophone player, described his frustrating first experience of working at a laïkó nightclub, I asked him what his criteria would be for accepting such a job again. He replied:

I would ask for a contract, that's the most basic. And if that wasn't an option, then the circumstances would have to be a bit better. More reasonable working hours. Not to play until dawn, right? The hours are important. And the money to be good, of course!

Whenever I asked musicians about the music-making itself, they tended to discuss it in terms of non-creative labour and particularly the lack of expressive freedom constraining their musicality. The target of criticism is invariably the singer, often referred to as 'the boss' 
or as 'the Uncle/Aunt', both characterisations stressing their role as employers and powerholders rather than as fellow musicians:

They [the singers] don't want to sit down and really play music. No intention of creating anything, you know? They just want to get the work over with ... And you feel like you have a speed limit. That you can go with $120 \mathrm{~km} / \mathrm{h}$ and they won't let you go more than 50. (Pétros V., bassist)

The bands are good, but the ones controlling the game, the producers and singers, they are very dodgy. So they make you [the instrumentalist] play dodgy 'cause if you're good then it's obvious how dodgy they are. If everyone is dodgy then no one notices the difference and it's all good for them. (Aléxandros K., drummer)

I was working with $\mathrm{P}-$ [singer] and he was a great boss. Relaxed, good fun to hang out with and all. But he was a terrible musician. Imagine, he added us to his band so that the whole thing would be a little more sophisticated than with his previous group. And instead of him trying to get better and play at our level, we had to get down to his! We couldn't wait for the one song he wasn't singing so we could play some music. (Pétros V., bassist)

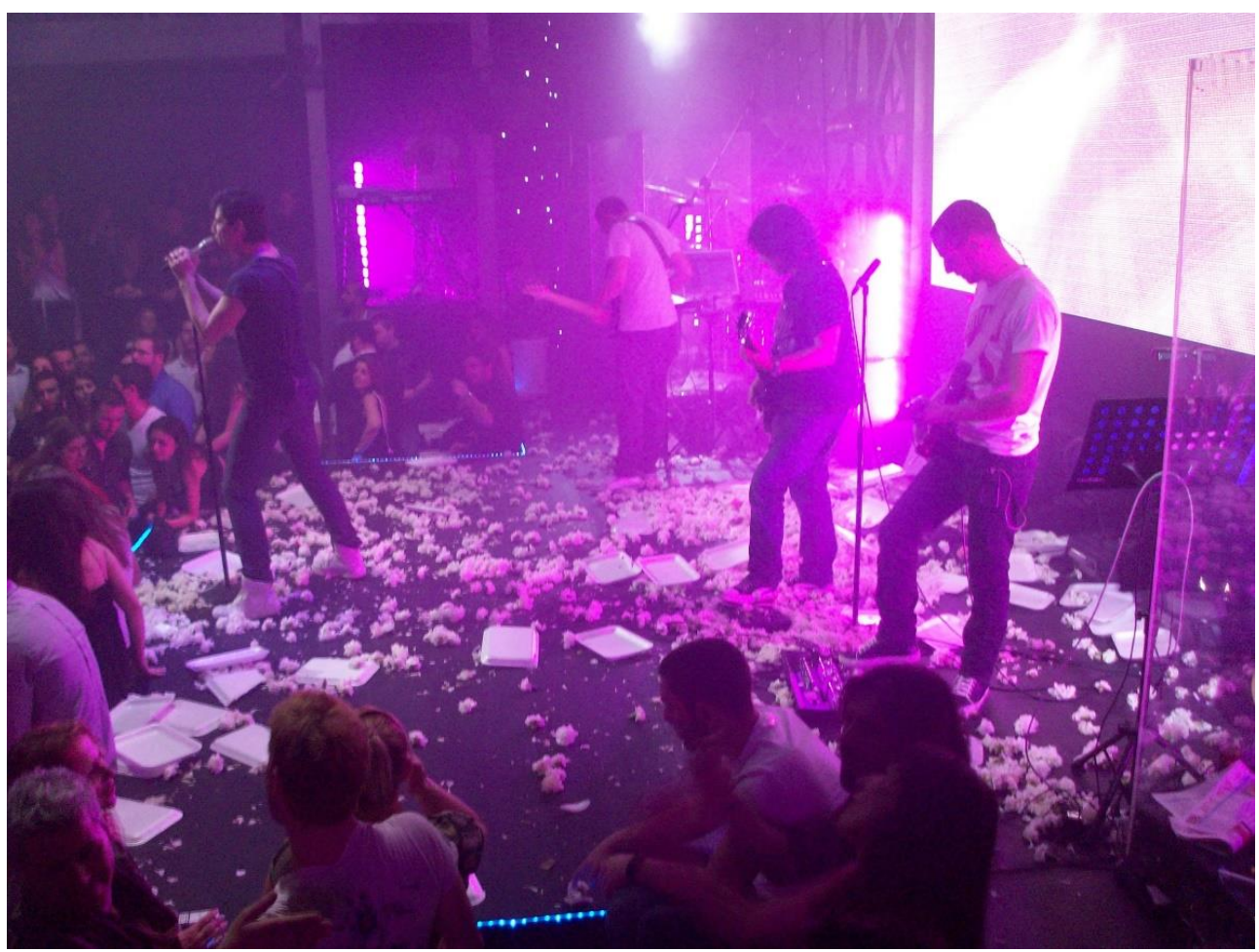

Figure 1

Session instrumentalists at work behind pop singer in a large Athenian nightclub. Source: Photograph by the author, 2009. 
Choosing not to work for the popular music industry and attempting to make a living from jazz alone, is generally considered a hard - but hugely respected - decision:

I decided to change contexts, I moved away from the money. I made choices that made my financial life very hard. But I'm enjoying my life now, and I'm playing less and less 'bad' notes. (Pétros V., bassist)

This pianist friend of mine told me last night: 'I'm trying to resist the money call. It's not easy but I'm trying!' (Pantelís P., trumpeter)

Since I gave up the 'night jobs', I discovered that I can live while spending less money. That was an important lesson ... I want to keep it this way. Now I only play for my pleasure and I'm preparing some of my own original material in a more jazz style. (Vásso D., guitarist)

This is precisely why the establishment of a jazz music department was initially regarded as a positive development by musicians, providing secure employment whilst also giving them time to play their own music.

The ways in which jazz musicians in Athens position themselves ideologically against the mainstream music industry, as well as their conception of musical labour, resonates strongly with the case of jazz musicians in Chicago in the 1940s and 1950s, as reported by Howard Becker $(1951,1963)$, who discusses how musicians constructed a community in opposition to outsiders who were referred to as 'squares' and despised for their lack of musical knowledge, sensitivity and 'hipness'. Through the view that 'it is the square's ignorance of music that compels the musician to play what he considers bad music in order to be successful' (1951:139), outsiders came to be regarded as potentially dangerous, leading to an intentional isolation of jazz musicians from audiences and the broader community (Becker 1951:141-4). Ford (2008) has recently argued that the division between the 'hipster' and the 'square' has defined the aesthetic ideologies of US jazz for over 50 years, the 'hip' style being driven by 'a conception of the individual's alienation from society-alienation that is due not to any specific political wrong but to something more 
radical, a clash of sensibility and perception' (2008:122-3). Merriam and Mack have also elaborated on the phenomenon of jazz musicians' social segregation:

The musician's conception of his own music, plus his inability to express this conception except to those who already understand, as well as his view that the commercial necessities of life are forced upon him by a society which does not realize he is a creative artist, all combine to contribute toward his view of the outside world as essentially hostile and to reinforce his sense of belonging to an isolated segment of society. (1960:217)

Similarly, sociologist Robert Stebbins has identified an array of patterns of 'role distance behaviour' employed by US jazz musicians as a strategy of disassociation from performances that are perceived as a 'threat to [their] self-conception' (1969:406). His description of the verbal and gestural signs intended to show musicians' general disengagement appears similar to the behaviour of jazzmen working in the mainstream popular music industry in Athens.

What I am suggesting here is not that the experience of the contemporary Athenian jazz musician is profoundly similar to the circumstances that Becker, Merriam and Mack, and Stebbins describe. In fact, the narratives and behaviours of the musicians that I talked to appear so suspiciously resonant with the ideas of their transatlantic counterparts that one might argue that they are drawing directly on them. This is a good example of Slobin's notion of affinity interculture: the fact that the image of the isolated and misunderstood-bysociety jazz musician travels through time and space to appear in twenty first-century Athens, happens neither by chance nor because the cultural factors are identical. This empathy reveals a cosmopolitan imaginary at play, drawing on decades-old processes of myth making and literary and audio/visual stereotyping. ${ }^{18}$ Such processes have also been

\footnotetext{
${ }^{18}$ Indeed, the very fact that the US jazz musician in the second half of the twentieth century managed to transcend his (gender specificity intended) social boundedness and enter the industry of widely circulated popular music, is precisely what makes this intercultural affiliation imaginable in contemporary Athens. The fact that several jazz autobiographies (for instance, Davis 1991; Mingus 1981) have been translated into Greek stands as an example of this universalising phenomenon.
} 
reinforced by the narratives of returning musicians who studied abroad, thus becoming carriers of 'cosmopolitan authenticity'.

The fact remains, however, that this identification with the archaic stereotype of the subaltern, African-American jazz musician is restricted by the Athenian circumstances within which musicians have to operate. Local jazz musicians would be eager to adopt a rigid characterisation of 'squares' for all outsiders if only they were certain that they themselves would qualify as 'hip'. Therein lies their initial objection to being classified as 'jazz musicians': it reveals their perceived incapacity to live up to the myths and fantasies surrounding this role. Moreover, their inability to form a self-sustainable, bounded jazz community as described by Becker, Merriam and Mack, and their obligatory constant interaction with outsiders (audiences, pop stars, entrepreneurs) in order to ensure economic survival, creates a need for more variable descriptions than the 'square' aphorism provides. In other words, jazz musicians in Athens do not have the luxury to discard outsiders altogether and live within their own 'hipness' by indulging in what Ford calls 'the aesthetic and the sensibility of counterculture' (2008:123), so they instead construct their criticisms based on the specificities of their relationship with these outsiders. An example of this can be found in the ways that musicians describe club owners for whom they have worked:

The owner treated us as if he was our pimp. He saw us as his employees rather than a band. He would tell us what songs to play, he brought another singer and added her to the band, he said we had to start at 12.15am and play until 5am and he would make phone calls when he wasn't there to make sure that we kept up with the schedule. He measured our musical ability by the number of tickets he sold. He had no other way to judge since he couldn't tell if we were good or bad players. (Yiórgos L., drummer)

A current club owner could previously have been a butcher or a crook. It doesn't matter ... There is no 'average' club owner, no average club owner mentality. It's just different people who are in it for the money! ... And you're in all this mess because you happened to love music once and now you have an instrument in your hand and a family to provide for. And your blood pressure 
peaks every night because the owner cheated you with money or the manager undermined you. (Vásso D., guitarist)

The above perspectives contrast with musicians' descriptions of audiences:

After a few days of work you see people like sheep. You can't connect with them. When you go to the club and there are 1,500 people there every night, they're all the same. They're just heads. (Antónis D., saxophonist)

The perceived inability of outsiders to judge musicians' performative value remains at the core of the problem. Nonetheless, the different roles that actors occupy in musicians' descriptions of professional music circuits suggest a more complicated terrain of power negotiations than a simple division between 'hip' and 'square'. In their representation of the processes that constrain their musicality, jazz musicians identify actors with variable power and diverse agendas, some of which, as will be discussed below, are no less cosmopolitan than their own.

\section{Playing}

A variety of alternative music scenes flourish in Athens on the nights when the large nightclubs are closed (Monday to Wednesday). Jazz is one of the most prominent, with musicians using the opportunity of their nights off to either play or watch performances. Venues such as Bacaro, Café Alavastron and the Paráfono Jazz Club feature mainly jazz performances, while a range of other clubs host jazz events three or four nights per month. ${ }^{19}$ In every jazz gig, one finds more musicians in the audience than on stage, a fact revealed when they are eventually invited to 'jam' with the officially featured group. In these events,

\footnotetext{
${ }^{19}$ Sadly, since the Greek economic collapse in 2010 and the imposition of severe austerity measures, most of these small venues have not been profitable and are threatened by bankruptcy. Whilst this article was being written, the Paráfono Jazz Club, the oldest among them, was (and remains) temporarily closed.
} 
jazz musicians get fleeting experiences of their ideal music-making, defined by experimentation, playful creativity and egalitarian participation which leads to an achievement of 'energy flow' ${ }^{20}$ These largely invisible scenes provide a subcultural haven for professional musicians who indulge in pleasurable music practices away from the gaze of their employers in the music industry. In this sense, the jazz community of 'play' works as a 'hidden transcript' (Scott 1990) in contrast with musicians' otherwise subaltern social lives in the popular music scene. By engaging in jazz music making, Athenian instrumentalists exorcise the everyday constraints imposed on them by the rigid hierarchies of the music industry. 'Play' is about the pleasure of experimentation enhanced by the negation of the structures of authority that traverse the 'work' setting. Pleasure, then, is as much political as it is musical. ${ }^{21}$

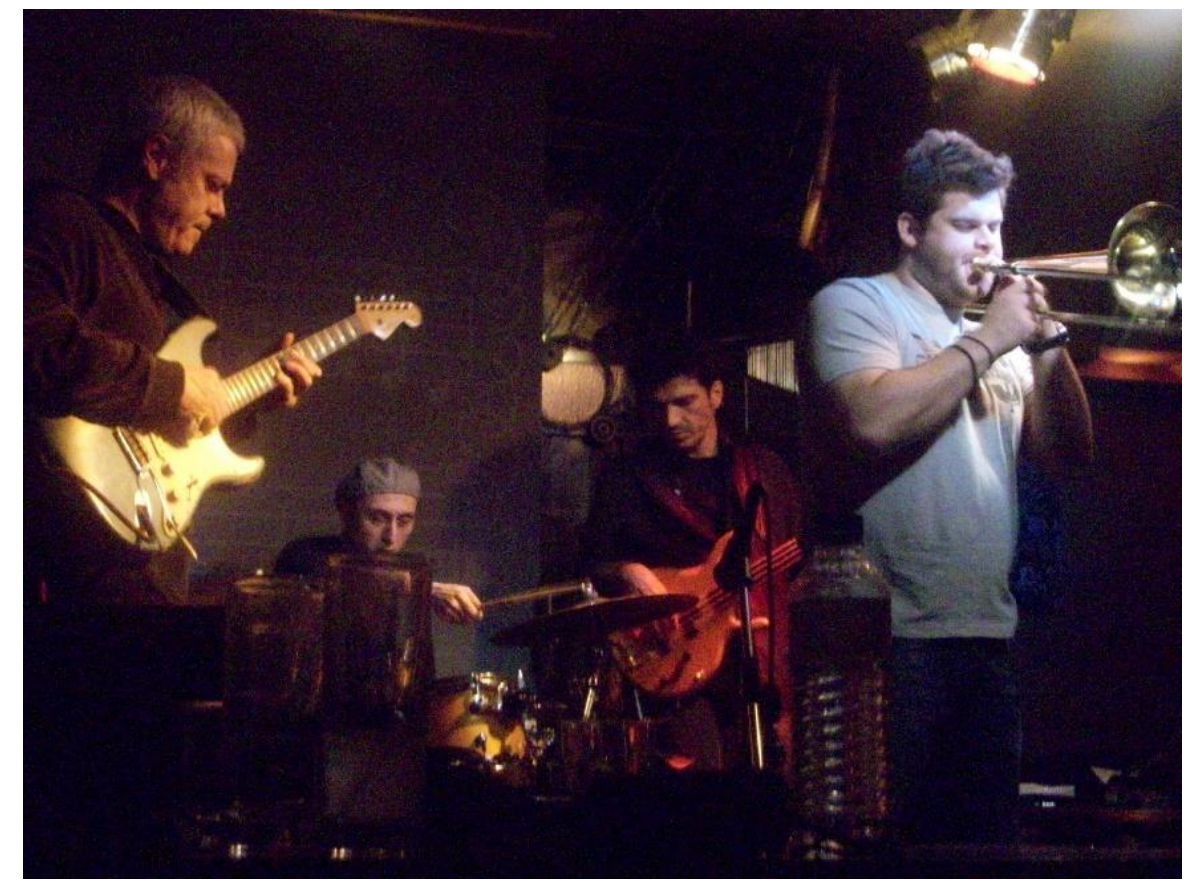

\section{Figure 2}

Jazz band The Sphere Project performing at Café Alavastron, Athens. Source: Photograph by the author, 2009.

\footnotetext{
${ }^{20}$ Musicians that I spoke to used this expression (frequently in English) to describe a feeling of collective engagement through jazz performances (see Tsioulakis forthcoming, 2012). Elina Hytönen (2010) has also elaborated on the ways in which experiences of 'flow' and the achievement of 'altered states of consciousness' are articulated among Finnish and British jazz musicians.

${ }^{21}$ Elsewhere, I have argued that professional musicians also use life narratives and private discussions as discursive spaces for the symbolic subversion of social hierarchies (Tsioulakis in press, 2011). Our private interviews often served as an opportunity for musicians to express their ideological consciousness and to undermine the authority of the power-holders of the work setting, engaging in what I call 'discursive resistance'. Similarly, occasions of musical play provide the stage for the performance of such resistance in musical terms.
} 
The criticism of the popular industry on the one hand, and the vision of a sustainable 'quality' (mostly instrumental) music scene on the other, provide grounds for some ideological unity within the community of jazz-trained musicians in Athens. A strong notion of cosmopolitanism is expressed through a somewhat constant underlying belief that 'everything is better abroad':

My teacher was an incredible trumpet player. He could have been a world master! But he was unlucky enough to be born in Greece. No good musicians are ever appreciated here ... Greece would never manage to have a jazz scene like Hungary. Never mind the States. (Pantelís P., trumpeter)

There are no venues to play here. Take Belfast, for example. Must be a city of ... what? 500,000 people? I bet there are at least five decent jazz clubs. And in the Athens of 5 million there aren't any! ... I have done some teaching in America. Students there know what they want. Here, I asked once a student which sax player did he like and he said Bill Clinton! (Antónis L., saxophonist)

Here, Antónis refers to Belfast (knowing that it serves as my academic base) as an example of a Western European city that - by default - must have a more vibrant jazz scene than Athens. In fact, this is far from the truth: ${ }^{22}$ we can thus recognise in Antónis' declaration an imaginary of 'Western Europe' that Athens, from his viewpoint, has been unsuccessful in reaching.

Of course, the idea that the jazz scene in Athens is less active than that of some other European urban centres is not a complete fantasy. Giorgos Haronitis, chief editor of $J a z z \& T \zeta \alpha \zeta$ magazine and the most renowned jazz music journalist in Greece, explains this as a consequence of the 'dark period' - by which he primarily means the Dictatorship of the Colonels which lasted from 1967 to 1974 - that Greece went through when other European countries were developing 'their own jazz' (2005) and which, according to Haronitis, served to exclude Greece from the loop of European jazz innovation at this time.

\footnotetext{
${ }^{22}$ To my knowledge, Belfast has no specialised jazz music venues; the weekly number of jazz gigs there is in fact a fraction of those taking place in Athens.
} 
This argument could be extended back to include a series of earlier historical conditions that stunted Greek cultural production at the time when swing, and later bebop, were becoming influential in Europe: during the Metaxas Dictatorship (1936-1940), the Nazi Occupation (1941-1944) and the Greek Civil War (1946-1949). What I am suggesting, however, is that the cosmopolitan imaginary of Greek jazz musicians longs for an almost unachievable 'jazz life' that is believed to exist somewhere outside the borders of Greece. And yet, the ideal of a jazzman as a creative artist who has solved his financial preoccupations and performs within a circuit of knowledgeable, appreciative audiences is clearly untenable even in countries such as Britain, Japan and the United States. ${ }^{23}$

The shared denigration of the popular music industry as a basis of cosmopolitan rhetoric, however, does not imply that the community is ideologically homogenous. Indeed, the different - often contradictory - nuances of cosmopolitanism in the viewpoints of musicians make the community appear surprisingly fragmented for its size. Below, I describe two examples which illustrate such ideological discrepancies: the case of ethnicjazz; and the Half Note Jazz Club controversy.

\section{Ethnic-Jazz: A Fragmented Cosmopolitanism}

One of the phenomena associated with the spread of jazz around the globe is the emergence of local discourses of authenticity, and in particular the debate over the extent to which local jazz should 'sound local'. Discussing the reception of jazz in India, for instance, Pinckney asserts that while some Indian musicians considered jazz improvisation a unique medium

\footnotetext{
${ }^{23}$ Atkins presents an image of the Japanese jazzman as a 'musician who spends hours a day practicing, who performs for less than transportation expenses, and who will be lucky to record for a small independent label' (2001:8) According to Christian, British jazz musicians 'are only too glad to get the chance to play something more to their taste and with more freedom of expression even for very little money' (1987:224). And Ford reports that, even in the United States, 'by the mid-1980s, it was clear that jazz's continued health as an art form was dependent on the support of charitable foundations and nonprofit arts organizations' (2008:124).
} 
for 'honest' expression that comes from 'the depths of the soul' (1990:53), others objected to any blend of Indian music and jazz that might 'ruin' both genres (ibid:54). Atkins (2001) has also illustrated a series of 'authentication strategies' employed throughout the history of Japanese jazz, some involving mimicry of US styles whilst others represent efforts to make the music sound quintessentially Japanese. In Sweden, Johan Fornäs (2003) has identified a variety of contesting viewpoints concerning the direction that jazz music production should take. Bakriges suggests that European attitudes towards jazz can be summarised under two main views: first, as an homage to black music; and second as a creative idiom for improvisation (2003:103). These two positions can be clearly identified in the Greek debate between 'mainstream' and ethnic-jazz.

The roots of ethnic-jazz can be found in a wider multicultural sensibility that arose in urban Greece during the 1990s (Vernikos and Daskalopoulou 2002) and manifested itself in a general taste for the 'exotic' within the fields of music, decoration and cuisine. This aesthetic was also central to the revival of traditional music in Athens, the so-called paradosiaká (Kallimopoulou 2009), which was triggered by the import and indigenisation of 'eastern' instruments such as the oúti, the kanonáki and the néy. Within this circuit, the term 'ethnic' was used in derogatory sense to describe a blend of traditional and contemporary musical idioms, neither of which was adequately represented by knowledgeable players (Kallimopoulou 2009:171) ${ }^{24}$ In the wider Athenian musical context, however, the term was used to denote world-fusion performances by both local and international artists. The tendency towards intercultural blends was further boosted by the establishment of music secondary schools with a curriculum that included compulsory training in traditional instruments (Dionyssiou 2000; Kallimopoulou 2009:135-46; Kapsokavadis 2010). In this way, state schools provided music students who had previously

\footnotetext{
${ }^{24}$ Kevin Dawe uses the term 'ethniki mousike' to refer to 'world music in Greece' (2007:178). However, the Greek word 'ethniki ( $\varepsilon \theta v \iota k \eta$ ) means 'national'. Greek musicians and audiences use the English 'ethnic', rather than the Greek 'ethniki, to describe 'exotic' music; this includes the 'non-national' and the neotraditional that incorporates cosmopolitan fusions.
} 
been educated in Western music with traditional instruments which served as a medium for improvisation and playful experimentation. ${ }^{25}$

This ethnic aesthetic was followed by a number of Greek jazzmen who integrated elements of the wider Balkan and Mediterranean traditions into their music in various ways. The group Mode Plagal, ${ }^{26}$ for instance, was one of the most successful at incorporating Balkan meters such as $15 / 16$ or $7 / 8,{ }^{27}$ whilst musicians such as Vassílis Rakópoulos ${ }^{28}$ and the bands Iasis ${ }^{29}$ and Checkmate in Two Flats ${ }^{30}$ experimented with a blend of Western and 'traditional' instrumentation. Other jazz musicians' cosmopolitan affiliations reached far beyond the Mediterranean. Prominent among them was the guitarist Tákis Barbéris who collaborated with Indian musicians such as Trilok Gurtu, Reshma Srivastava and Shankar Lal, for example on the albums Episodes (1995) and Naiva (1998).

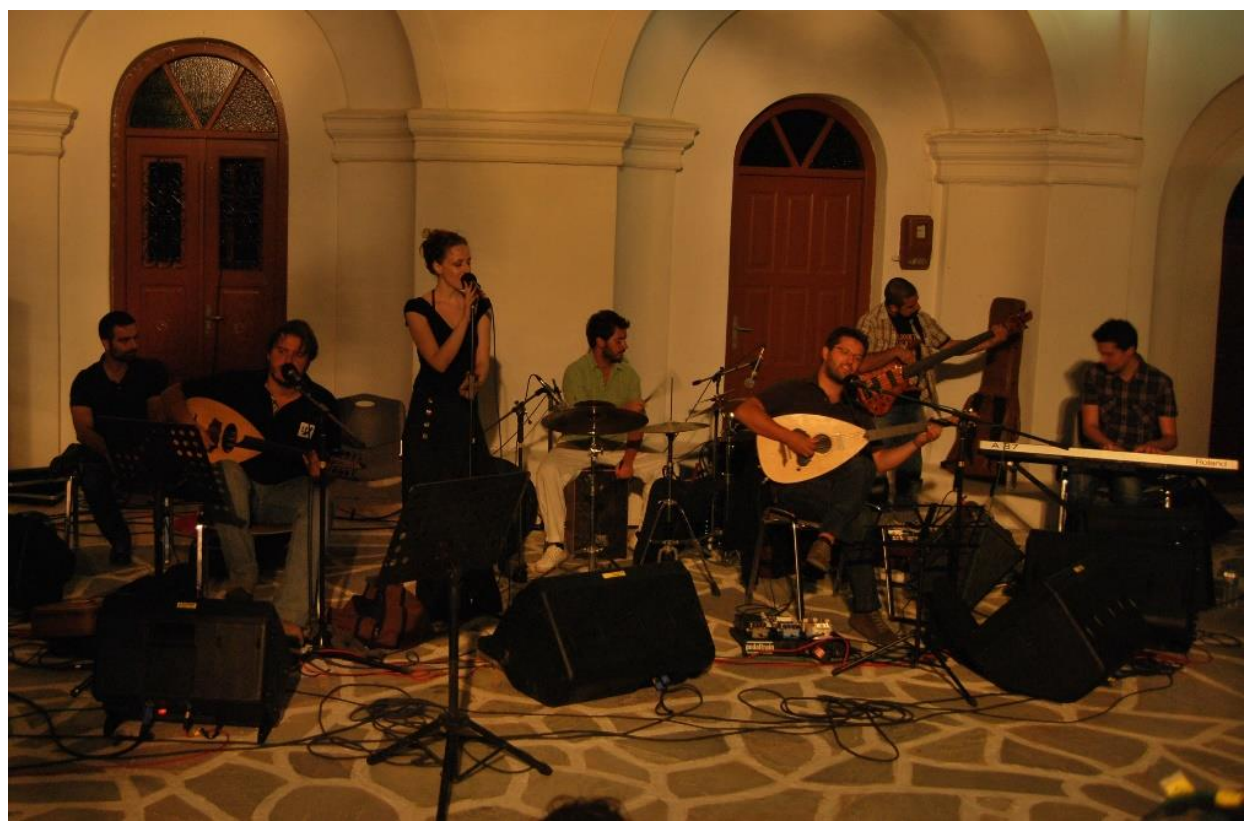

Figure 3

Checkmate in Two Flats performing at a summer festival on Paros Island. Source: Photograph courtesy of Dimitris Miyiakis, 2010.

\footnotetext{
${ }^{25}$ Juniper Hill (2009) has shown how experimental improvisation was employed by teachers at the Sibelius Academy in Helsinki as a training method in Finnish folk music. Kapsokavadis's (2010) research in Athenian secondary music schools, however, has suggested that in the Greek context the same thing occurred as an unintentional side-effect of the official educational policy.

${ }^{26}$ See Dawe (2007).

${ }^{27}$ The pieces 'Funky Vergina' and 'Ivo' respectively, from the album II (1998).

${ }^{28}$ See in particular his album Torch Dance (2001).

${ }^{29}$ For an analysis of the role of a traditional instrumentalist in Iasis' album Amalgama (1998), see Kallimopoulou (2009:153-4).

${ }^{30}$ The 2005 album Pséma san Alitheia, which features well-established guest musicians from both the jazz and the neo-traditional scenes, is a good example of this band's experimentation with instrumental combinations.
} 
These intercultural blends are met with purist scepticism from both traditional Greek and jazz musicians. ${ }^{31}$ Within the jazz scene, the main debate concerns notions of 'Greekness' and the extent to which it should inform local jazz production. Musicians' discourses include strong references to authenticity, or 'honesty' as it is often expressed:

The reason why jazz died in Greece is because everyone thought that by putting an oud into their music they made it trendy. They thought everyone will love this new ethnic-jazz. And they failed. We who remained loyal at least survived ... If I put Greek stuff into my music it wouldn't be honest. I am dedicated to jazz. (Antónis L., saxophonist)

I have written pieces that sound like Brad Mehldau and others that have themes and modes from Cretan music. One of them I have dedicated to a Cretan lýra player. I would not be honest if I composed music that had a hundred percent New York sound. It wouldn't come out naturally. If it's honest it must have something showing where I come from. (Aléxandros D., drummer)

In these quotations, the word 'honest' is used in two contrasting ways in relation to claims of authenticity: in the first, Antónis is being authentic by ensuring the (jazz) 'purity' of his music-making; in the second, Aléxandros asserts that only musical hybridity can successfully account for his double identity as a jazz musician and a Cretan native. ${ }^{32}$ We thus observe a conflict between two kinds of honesty: to one's cosmopolitan imaginary and to one's native culture. An additional irony here is that the purist stance is not linked, as the familiar story goes, with the preservation of a musical tradition; on the contrary, it proclaims loyalty to jazz, a transnational cultural formation. It is, then, the quest for the advocates of hybridity to legitimise the authenticity of their music aesthetic by showing that they possess an experiential knowledge of all the incorporated idioms.

\footnotetext{
${ }^{31}$ For a detailed discussion of purist discourses and the debates over authenticity within the Athenian neotraditional scene, see Kallimopoulou (2009).

${ }^{32}$ Stokes has identified such attitudes as intrinsic to academic ethnomusicological work itself, asserting that outright hostility towards invented national traditions has established hybridity as the new authenticity (2004:60-1).
} 
This conflict should not be perceived as exemplifying the extremes of a cosmopolitan vs nationalist dualism. Indeed, as Turino has argued (2000), nationalism is itself best understood within a cosmopolitan framework. In the case of Greece, ethnic-jazz enthusiasts present as their main motivation the building of a local jazz scene that can justify itself in a global market by using a transnational musical idiom while incorporating local elements. This aspiration explains their persistence in producing CDs with titles and liner notes in English (or in English and Greek) even though these products rarely enter the world market. It seems, however, that the strategy of ethnic-jazz practitioners is not entirely unsuccessful. In fact, the negativity of 'mainstream' jazzmen can partly be explained by their rarer appearance in international festivals compared with their 'ethnic' colleagues. ${ }^{33}$ This mode of thinking - a preoccupation with promoting the local music scene abroad - needs to be considered as a specific type of cosmopolitanism. Stokes has referred to a similar type of 'elite, intelligentsia cosmopolitanism, whose project was one of generating national art and folk musics, and various self-conscious acts of musical syncretism connecting local content with "universal” and "modern”, i.e. western, techniques' (2007:7).

The debate over what 'honest' Greek jazz music should sound like also invokes a broader discussion over who has the authority to talk about jazz in the first place. Vásso, a female guitarist trained in the US, commented on jazz purists in Greece:

Jazz in Greece suffers from excessive academism. Once I heard a guy saying: 'Oh, jazz died in the 60s. Maybe it lasted until 1965 but that was it. And you, all these years in America and still haven’t caught on!' And this coming from a guy that is fed by his wife's salary and, from what I know, hasn't travelled as far as Spain to see the Atlantic! I got furious! I was like 'have you lived in Harlem? Got chased by the US tax office? Stayed homeless in NY for a while? What's your experience? How do you get to talk about jazz?'

\footnotetext{
${ }^{33}$ One jazz pianist told me that at the height of the 'ethnic' aesthetic in the 1990s: 'I would get more jobs if I studied oúti for a year than what I get now for playing the piano since I was six years old'. Tina K. Ramnarine reports a similar phenomenon in Finland where musicians equated the ability to play folk instruments with opportunities to travel and perform around the world (2003:202).
} 
Vásso stresses both her physical presence at the locus where jazz was fostered and developed; and further exerts her authority by emphasising jazz as a subaltern music connected to its former subcultural character as opposed to its more recent supercultural global appeal. Her experiences as an outcast of US society (homeless, chased by the government) are used as an existential link to jazz culture, something which in her view cannot be substituted by mere listening and playing.

\section{The Half Note Jazz Club and Cosmopolitan Exoticism}

Another interesting point of conflict has emerged between local jazz musicians and the Half Note Jazz Club, the latter often criticised for its failure to provide a stage for Greek musicians, instead featuring primarily foreign artists. For local musicians, this represents a false form of cosmopolitan authenticity: they joke about the deep-voice style used in radio advertisements for the club and epithets seeking to stress the authenticity of visiting artists: 'the priestess of American jazz' or 'straight from the shores of the Mississippi river', and so on:

The Half Note promotes only foreign music because it gets foreign sponsorship. It plays with people's imagination of the exotic, and has done nothing to support the Greek jazz scene. (Pantelís P., trumpeter)

The Half Note is contributing to the idea that jazz cannot but be 'black' and 'foreign' ... They will promote a blues-man just because he's black. He could be from Uganda! But he's black so he must be better than the Greek blues musicians. So the media love them, but it's very bad for the local scene. (Antónis L., saxophonist)

The contradictions are evident here: local jazz musicians allow themselves to dismiss the mainstream Greek popular music scene even though they contribute to it as paid session instrumentalists. Under no circumstances, however, are they to be dragged into the 'pit of 
decadence' associated with it by outsiders such as the Half Note management. By drawing lines between their work and their playing, their labour and art, they wash their hands of what is regarded as low quality local production, and declare that, given the chance, they could do better. The Half Note, on the other hand, is seen as promoting an image of cosmopolitanism that portrays jazz as an unreachable music culture that only inhabits exotic loci, a music that Greek audiences have to import and consume in small doses.

The Half Note is all about the image: 'can we bring a colourful band that has a black singer? The best show!' The good thing is that, even the ignorant who will be preoccupied with matching his shoes to the club's pavement and his girlfriend's dress who he brought to impress, the one who came to have some good wine - or so he thinks! - while watching these bizarre foreign performers who have to be foreign - he will still listen to some good music. It won't be the greatest shock for him if later on his son brings a saxophone into the house. It will remind him of that night. (Vásso D., guitarist)

Thus, for Vásso, the Half Note management's attitude can only be beneficial if it provides opportunities for a thriving local jazz scene to emerge. This last quotation touches on a more subtle aspect of musicians' condemnation of Half Note's practices: the survival of the jazz musician. ${ }^{34}$ The underlying implication is that, unless local entrepreneurs recognise the ability of Greek musicians to lead a profitable jazz scene, the country will never overcome its exclusion from the circuit of European jazz. This is a further example of how local interests inform competing ideas of cosmopolitanism.

The disjuncture between the Half Note aesthetic and jazz musicians' preoccupations also helps to clarify the denial of the historical presence of jazz in Athens before the 1970s. Many musicians regard elafró tragoúdi as an example of the same false bourgeois cosmopolitanism that drives the programming decisions of the Half Note, an attitude which they consider detrimental to their quest for a truly innovative local jazz scene defined by musical excellence.

\footnotetext{
${ }^{34}$ White (1987:194) has also shown how Swiss jazz musicians suffered from the fact that local jazz clubs preferred foreign musicians as both more 'authentic' and cheaper.
} 


\section{Conclusion}

According to Martin Stokes,

Musical cosmopolitanism may well be understood ... as the product of certain kinds of intentionality and agency, which we might appropriately understand politically and culturally. But to neglect the element of pleasure and play in the global circulation of musical practice would, it seems to me, also be to make a serious mistake. (2007:15)

The theorisations of the social imaginary discussed at the start of this paper represent efforts to transcend the dilemma between political/cultural intentionality and pleasure or play. An engagement with the idea of the imaginary presupposes a view of cultural politics as indistinguishably intertwined with fantasies and pleasure. This assertion does not intend to downplay the reality of the impact of cultural politics in global or local contexts. On the contrary, my aim has been to show how cultural practices come into being whilst acknowledging the real, the potential, and the fantasy. Moreover, this line of thought recognises the role of individual and collective agencies of various scales in this process.

This exploration of the Athenian jazz scene has sought to trace the transformation of an 'affinity interculture' into a subculture, a transformation which is socially-informed: through their identification with the 'subaltern' jazz musician, Athenian instrumentalists negotiate their social self-conception. However, this results in a rather uncomfortable subculture comprising many more performers than fans. And I would willingly leave aside these neat categorisations of performer and audience if my informants were also eager to do so. But the evident frustration created by the lack of a proper audience and the resulting inability to live the 'jazz life' as it exists in their cosmopolitan imaginaries suggests that they are not. Jazz music in Athens should be understood as a result of cosmopolitan projects rather than globalist forces because of that very essence: it is accessed by a specific local musical intelligentsia who, despite their intentions, have not succeeded in making it a widely 
shared culture. Moreover, as I have sought to illustrate through the diverse and somewhat contradictory ideas invoked under the wide umbrella of cosmopolitanism, Athenian jazz cosmopolitanism is not even consistent within itself, something which contributes to an understanding of jazz music-making in Athens as a terrain for contested individual imaginaries rather than harmonically collective ones. Returning to my opening point, one can better understand why many musicians feel uncomfortable with the label jazz musician': because 'Greek plus jazz' is perceived as a paradox in itself. If Greece is not a country for jazzmen, this is because their fantasies sit uneasily between a local reality that has no room for them and an imagined transnational community that their music cannot reach.

\section{References Cited}

Anderson, Benedict R. 1983. Imagined Communities: Reflections on the Origin and Spread of Nationalism. London: Verso.

Anonymous. 2001. 'O Tzentleman tis Ellinikis Mousikis, Spartakos' ('Spartakos, the Gentleman of Greek music'). Kathimerini ( ${ }^{\text {st }}$ August 2001). http://news.kathimerini.gr/4dcgi/_w_articles_civ_2_01/08/2001_5000028 (accessed 16 June 2010).

Appadurai, Arjun. 1990. 'Disjuncture and Difference in the Global Cultural Economy'. Public Culture 2(2):1-24. . 1996. Modernity at Large: Cultural Dimensions of Globalization. Minneapolis: University of Minnesota Press.

Atkins, E. Taylor. 2001. Blue Nippon: AuthenticatingJazz inJapan. Durham N.C.: Duke University Press. . 2003. 'Toward a Global History of Jazz'. In Jazz Planet, edited by E. Taylor Atkins, xi-xxvii. Jackson: University Press of Mississippi.

Bakriges, Christopher G. 2003. 'Musical Transculturation: from African American AvantGarde Jazz to European Creative improvisation, 1962-1981'. In Jazz Planet, edited by E. Taylor Atkins, 99-114. Jackson:University Press of Mississippi.

Becker, Howard S. 1951. 'The Professional Dance Musician and his Audience'. American Journal of Sociology 57(2): 136-44.

. 1963. Outsiders: Studies in the Sociology of Deviance. Glencoe: Free press.

Born, Georgina and David Hesmondhalgh. 2000. 'Introduction: On Difference, Representation, and Appropriation in music'. In Western Music and its Others: 
Difference, Representation, and Appropriation in Music, edited by Georgina Born and David Hesmondhalgh, 1-58. Berkeley: University of California Press.

Castoriadis, Cornelius.1987. The Imaginary Institution of Society. Cambridge, Mass.: MIT Press.

2000. 'Anthropologia, Filosofia, Politiki' ('Anthropology, Philosophy, Politics'). Nea Koinoniologia 31: 17-26.

Christian, Harry. 1987. 'Convention and Constraint among British Semi-Professional Jazz

Musicians'. In Lost in Music: Culture, Style, and the Musical Event, edited by Avron Levine White, 220-40. London and New York: Routledge and Kegan Paul.

Cowan, Jane K. 1993. 'Politics, Identity and Popular Music in Contemporary Greece'. Kampos: Cambridge Papers in Modern Greek 1(1): 1-22.

Davis, Miles. 1991. Máils: Aftoviografía (Miles: The Autobiography). Translated by M. Massárou. First published in English 1990. Athens: Selas.

Dawe, Kevin. 2007. 'Regional Voices in a National Soundscape: Balkan Music and Dance in Greece'. In Balkan Popular Culture and the Ottoman Ecumene: Music, Image, and Regional Political Discourse, edited by Donna A. Buchanan, 175-91. Lanham, MD: Scarecrow Press.

Dionyssiou, Zoe. 2000. 'The Effects of Schooling on the Teaching of Greek Traditional Music'. Music Education Research 2(2): 141-63.

Erlmann, Veit. 1999. Music, Modernity, and the Global Imagination : South Africa and the West. New York: Oxford University Press.

Ford, Phil. 2008. 'Hip Sensibility in an Age of Mass Counterculture'.Jazz Perspectives 2(2): 121-63.

Fornäs, Johan. 2003. 'Swinging Differences: Reconstructed Identities in the Early Swedish Jazz Age'. In Jazz Planet, edited by E. Taylor Atkins, 207-24. Jackson: University Press of Mississippi

Gaonkar, Dilip P. 2002. 'Toward New Imaginaries: An Introduction'. Public Culture 14(1): $1-19$.

Hannerz, Ulf. 1992. Cultural Complexity: Studies in the Social Organization of Meaning. New York and Oxford: Columbia University Press.

Haronitis, George. 2005. 'I Elliniki Tzaz Simera' ('Greek Jazz Today'). Epta Imeres Magazine (23 January 2005).

http://www.kathimerini.gr/4dcgi/_w_articles_kathglobal_2_23/01/2005_1283677

(Accessed 16 June 2010).

. 2006. 'A History of Greek Jazz'. http://www.jazzntzaz.gr/history.html (Accessed 16 June 2010).

Herzfeld, Michael. 1982. Ours Once More: Folklore, Ideology, and the Making of Modern Greece. Austin: University of Texas Press. (1st edition).

Hill, Juniper. 2009. 'Rebellious Pedagogy, Ideological Transformation, and Creative Freedom in Finnish Contemporary Folk Music'. Ethnomusicology 53(1): 86-114.

Hytönen, Elina T. 2010. 'Moments of Bliss and Transcendence in Jazz: Professional Jazz Musicians' Reports of Flow Experiences'. Ph.D. Diss., University of Joensuu, Finland. 
Inda, Jonathan Xavier and Renato Rosaldo. 2008. 'Tracking Global Flows'. In The Anthropology of Globalization: A Reader, edited by Jonathan Xavier Inda and Renato Rosaldo, 3-46. Malden, MA: Blackwell. (2 $2^{\text {nd }}$ edn.).

Kallimopoulou, Eleni. 2009. Paradosiaká: Music, Meaning and Identity in Modern Greece. Farnham: Ashgate.

Kapsokavadis, Alexandros. 2010. 'Organo Ipostiriktiko: O Tambouras os Enallaktiki Morfi Mousikis Didaskalias' ('Supportive Instrument: Tambouras as an Alternative Form of Music Education'). MA Diss., University of Athens, Greece.

Kater, Michael H. 1992. Different Drummers: Jazz in the Culture of Nazi Germany. New York and Oxford: Oxford University Press.

Liavas, Labros. 2009. To Elliniko Tragoudi Apo to 1821 Eos ti Dekaetia Tou 1950 (Greek Song From 1821 to the 1950s). Athens: Emporiki Trapeza.

Lipsitz, George. 1994 Dangerous Crossroads: Popular Music, Postmodernism and the Poetics of Place. London; New York: Verso.

Lykouropoulos, Sotiris. 2005. 'Sinedesan to Onoma Tous me Megales Epitihies' ('They Connected their Names with Big Hits'). Kathimerini (21 October 2005).

http://www.kathimerini.gr/4Dcgi/4dcgi/_w_articles_kathglobal_2_23/10/2005_1284691 (Accessed 16 June 2010).

Merriam, Alan P. and Raymond W. Mack. 1960. 'The Jazz Community'. Social Forces 38(3): 211-22.

Milonas, Kostas. 2002. Elliniki Mousiki: Istorika Orosima (Greek Music: Historical Milestones). Athens: Nefeli.

Mingus, Charles 1981. Heirótera Ki Apo Skyliá (Beneath the Underdog). Translated by Antonis Dimitriou. First Published in English 1975. Athens: Exantas Publications.

Monson, Ingrid. 1999. 'Riffs, Repetition, and Theories of Globalization'. Ethnomusicology 43(1): 31-65.

Panagakos, Anastasia. 'Downloading New Identities: Ethnicity, Technology and Media in the Global Greek Village'. Identities 10(2): 201-19.

Papanikolaou, Dimitris. 2007. Singing Poets: Literature and Popular Music in France and Greece. London: Legenda.

Pinckney, Warren R. 1990. 'Jazz in India: Perspectives on Historical Development and Musical Acculturation'. Asian Music 21(1): 35-77.

Polychronakis, Ioannis. 2007. 'Anna Vissi: The Greek "Madonna”?' Paper presented at INTER: A European Cultural Studies Conference in Sweden, Norrköping 11-13 June 2007. http://www.ep.liu.se/ecp/025/054/index.html (Accessed 16 June 2010).

Ramnarine, Tina K. 2003. Ilmatar's Inspirations: Nationalism, Globalization, and the Changing Soundscapes of Finnish Folk Music. Chicago: University of Chicago Press. Scott, James C. 1990. Domination and the Arts of Resistance: Hidden Transcripts. New Haven: Yale University Press.

Slobin, Mark. 1993. Subcultural Sounds: Micromusics of the West. Hanover, NH: University Press of New England. 
Starr, S. Frederick. 1983. Red and Hot: The Fate of Jazz in the Soviet Union, 1917-1980. New York and Oxford: Oxford University Press.

Stebbins, Robert A. 1969. 'Role Distance, Role Distance Behaviour and Jazz Musicians'. British Journal of Sociology 20(4): 406-15.

Stokes, Martin. 2004. 'Music and the Global Order'. Annual Review of Anthropology 33: 47-72.

2007. 'On Musical Cosmopolitanism'. The Macalester International Roundtable 2007. Available at http://digitalcommons.macalester.edu/intlrdtable/3/ (accessed 15 May 2011).

Taylor, Charles. 2002. 'Modern Social Imaginaries'. Public Culture 14(1): 91-124. 2004. Modern Social Imaginaries. Durham: Duke University Press.

Thornton, Sarah. 1995. Club Cultures: Music, Media and Subcultural Capital. Cambridge: Polity Press.

Tragaki, Daphne. 2005. "Humanizing the Masses": Enlightened Intellectuals and the Music of the People'. In The Mediterranean in Music: Critical Perspectives, Common Concerns, Cultural Differences, edited by David Cooper and Kevin Dawe, 49-73. Lanham, MD: Scarecrow Press. . 2007. Rebetiko Worlds. Newcastle: Cambridge Scholars.

Tsing, Anna. 2000. 'The Global Situation'. Cultural Anthropology 15(3): 327-60.

Tsioulakis, Ioannis. In press, 2011. 'At First I Saw it as a Toy: Life Stories, Social Consciousness and Music Ethnography'. Irish Journal of Anthropology 14(1).

. Forthcoming, 2012. 'The Quality of Mutuality: Jazz Musicians in the Athenian

Popular Music Industry'. In Music and Sociality in Urban Europe, edited by Carsten Wergin and Fabian Holt.

Turino, Thomas. 2000. Nationalists, Cosmopolitans, and Popular music in Zimbabwe. Chicago: University of Chicago Press. . 2003. 'Are we Global Yet? Globalist Discourse, Cultural Formations and the Study of Zimbabwean Popular Music'. British Journal of Ethnomusicology 12(2): 51-80. Vernikos, Nikolaos and Sophia Daskalopoulou. 2002. Polypolitismikotita: I Diastaseis tis Politismikis Taftotitas (Multiculturalism: The Dimensions of Cultural Identity). Athens: Kritiki.

White, Avron Levine. 1987. ‘A Professional Jazz Group’. In Lost in Music: Culture, Style, and the Musical Event, edited by Avron Levine White, 191-219. London and New York: Routledge \& Kegan Paul.

\section{Select Discography}

Barbéris, Tákis. 1995. Episodes. Athens: Lyra CD ML0177. Compact disc. . 1998. Naiva. Athens: Lyra CD ML0661.Compact disc.

Checkmate in Two Flats. 2005. Pséma san Alitheia (A Lie that Sounds True). Athens: Universal CD SKU1637. Compact disc.

Iasis. 1998. Amalgama. Athens: Lyra CD ML0664. Compact disc. 
Mode Plagal. 1998. II. Athens: Lyra CD 3401576304. Compact disc.

Page One. 1994. Page One. Athens: Utopia CD 105689652. Compact disc. . 1995. Beyond the Blue. Athens: FM Records CD 067455624. Compact disc.

Pléssas, Mímis. 1981. 40 Hrónia Jazz (40 Years ofJazz). Athens: Columbia LP 71205. Long playing disc.

Rakópoulos, Vassílis. 2001. Horós Ton Pyrsón (Torch Dance). Athens: E-terra CD ETM004. Compact disc.

Spártakos, Yiánnis. 1975. Relaxing with Yiannis Spartakos and his Golden Trio. Athens: Olympic LP SBL 1114. Long playing disc.

Sphinx.1979. Sphinx. Athens: ABCA: LP 0422. Long playing disc. 